\title{
EFFECT OF SUPPLEMENTING ALCOHOLIC AND AQUEOUS EXTRACTS OF SEEDLESS DATE AND DATE PITS OF KHALAL AL- ZAHDI DATE PHOENIX DACTYLIFERA L. TO DRINKING WATER ON SOME PRODUCTIVE TRAITS OF JAPANESE QUAIL HENS REARED UNDER HIGH TEMPERATURE
} Mohammed Rasul Mahdi Jasim ${ }^{1}$ Dhia Khalil Ibrahim ${ }^{2}$

${ }^{1}$ Mins. of Sci. and Techn. ${ }^{2}$ Anim. Prod. Dep., College of Agric. Eng. Sci., Baghdad Uni. Corresponding Author: Dhia Khalil Ibrahim ${ }^{2}$ Email: avphdidk@ yahoo.com] Received: 06/09/2020 Accepted: $25 / 10 / 2020$

\begin{abstract}
The study was conducted by using 225 quail females in the production stage at the age of 50 days from one hatchery at a rate of $185 \mathrm{~g}$ weight for 12 weeks, and randomly distributed to five experimental groups, at 45 quail females per treatment, and at a rate of 15 quail females for each replicate. The birds were exposed to temperature at a rate of $\left(28-36-30 \pm 2^{\circ} \mathrm{C}\right)$ and relative humidity at a rate of (40-60-50 $\pm 2 \%)$ for the time (700-1200-1900). The birds were fed a standard diet contain $20 \%$ crude protein and $2903 \mathrm{kcal}$ metabolizable energy $/ \mathrm{Kg}$ feed. The birds were distributed randomly as follows: The first group (T1) was the control without addition to drinking water, the second (T2) and the third (T3) groups with added $300 \mathrm{mg} / \mathrm{L}$ of water from the aqueous and alcoholic extract for the Al-Zahdi khalal date without pits, respectively, and the fourth (T4) and the fifth (T5) groups with added $300 \mathrm{mg} / \mathrm{L}$ of water from the aqueous and alcoholic for extract AlZahdi Khalal dates pits, respectively. The results indicated that there was a significant increase $(\mathrm{P} \leq 0.01)$ for all adding treatments compared to the control treatment with a preference in favor of the third and fifth treatments in the traits of egg production percentage on the basis of Hen-Day (H.D), mass, cumulative number of eggs, average weekly egg weight, weekly feed consumption, and significant $(\mathrm{P} \leq 0.01)$ improvement in feed conversion efficiency in most of the experimental periods. In conclusion, the use of these extracts contributed to improve the studied production traits of Japanese quail hens exposed to heat stress, noting that the treatments T3 and T5 recorded the best results for all studied traits and for most of the experimental periods of the study.
\end{abstract}

Key words: aqueous extract, alcoholic extract, Al-Zahdi Khalal dates , Al-Zahdi dates pits, quail. 


\section{INTRODUCTION}

The high temperature is one of the major problems facing the raising of poultry, where the rise in the temperature of more than $30^{\circ} \mathrm{C}$ for a long time leads to physiological changes in the hormonal behavior of the body and this phenomenon is called heat stress, which works to reduce feed consumption, weak immunity, and a high percentage of mortality causing major economic losses to poultry owners (Siegel, 1995; El-Lethy et al., 2000). Many researches have been conducted to reduce the negative impact of heat stress, either by adding vitamins like E (Al-Rahawi, 2010), fasting and adding salts (Ibrahim and Al-Hasani, 2002) or the use of medicinal and food plants, which represent less expensive and fewer alternatives in terms of side effects in addition to their medicinal and therapeutic benefits (Al Khailani, 2009). Among these alternatives is the use of the fruit and the pits of Al-Zahdi Kalal date extracts in drinking water for poultry, where it is characterized during ascetics by their content of vitamins such as C, $\mathrm{E}$ and $\mathrm{A}$ and the yellow phenolic pigments responsible for the yellow color, and classified as one of the most important non-enzymatic antioxidants (Al- Laith, 2007; Ghnimi et al., 2017). As for the Al-Zahdi Date pits it is characterized by its containment of many phenolic compounds and nutrients similar to the Date pits throughout the maturity stages of the Al-Zahdi dates fruit and has many medicinal uses as it is effective in treating infections (Awadalla et al., 2002).It is considered a good source and stimulates the immune system in the body in addition to being an antioxidant (Al-Turk,2008; Al-Juraisy, 2016).Studies have shown that the date fruit have a positive effect on the weight gain rates of fattening animals, due to the presence of chemicals similar to growth hormones which contributes to increasing the growth rates of animals and birds (Awadalla et al, 2002; AlQarawi et al, 2004; Al-Sawaf, 2011). Therefore, the main objective of the study was to know the effects that the aqueous and alcoholic extracts of the fruit and the pits of Khalal Zahdi date may contribute to relieve heat stress and observing the extent of their effects on some productive traits of Japanese quail hens exposed to heat stress.

\section{MATERIALS AND METHODS}

The alcoholic extract was prepared according to the method used by (Harborne et al. 1975; AlJuraisy et al., 2013). About $50 \mathrm{~g}$ of Al-Khalal and date pits powder were placed in a $1000 \mathrm{ml}$ glass beaker, $250 \mathrm{ml}$ of ethyl alcohol (ethanol) was added to it at an concentration of $70 \%$, then the beaker was placed on the Magnetic stirrer device to mix well for 24 hours at room temperature and the mixture was filtered by layers of gauze. Then, the prepared extract was placed in a flask of a rotary evaporator at a temperature of $40^{\circ} \mathrm{C}$ for the purpose of getting rid of ethyl alcohol and humidity and in order to obtain a dry powder for the date pits extract or in the form of a sticky substance for Khalal extract . As for the aqueous extract of the Alkhalal date and the dates pit of the Aqueous extract, it was prepared by adding $50 \mathrm{~g}$ of the Alkhalal and dates pit powder in a $1000 \mathrm{ml}$ glass beaker and $250 \mathrm{ml}$ of boiling water were added to it. The aqueous extract was prepared in the same methods where the alcoholic extract was prepared and the samples were dried at a temperature of $60^{\circ} \mathrm{C}$.

A total of 225 Japanese quail birds aged 50 days from one hatching were used at a rate of $185 \mathrm{~g}$ for a period of 12 weeks. They were randomly distributed to five treatments. Each treatment included 45 birds, three replicates per treatment, and 15 birds per replicate. The birds were raised in wooden floor cages designed with dimensions of $1 \mathrm{~m} 2$ equipped with a plastic feeder clip to ensure that the feed was not dispersed, as well as the use of inverted plastic fountains with a capacity of 5 liters, the use of 16 hours of lighting, followed by 8 hours of darkness. The lamps were placed at a height of $2 \mathrm{~m}$ from the cages to ensure that the birds get good lighting intensity. The birds were exposed to a temperature of $\left(28-36-30 \pm 2 \mathrm{~m}^{\circ}\right)$ and the degree of relaive humidity at an average of(40-60-50 $\pm 2 \%)$ for the times (7001200-1900) .The experimental groups were distributed as follows: 
The first group (T1) is the control, without any addition to drinking water

The second group (T2), adding the aqueous extract for the Al-Zahdi khalal date without pits at a ratio of $300 \mathrm{mg} /$ liter of drinking water.

The third group (T3), adding the alcoholic extract for the Al-Zahdi khalal date without pits at a ratio of $300 \mathrm{mg} / \mathrm{l}$ of drinking water.

The fourth group (T4), adding the aqueous extract for the Al-Zahdi khalal date pits at a ratio of $300 \mathrm{mg} /$ liter of drinking water.

The fifth group (T5), adding the alcoholic extract for the Al-Zahdi khalal date pits at a ratio of $300 \mathrm{mg} / 1$ of drinking water

The extracts were added daily to drinking water, a standard diet was used, the ingredients of which were calculated according to the recommendations of the National Research Council (N.R.C,1994). The protein content was $20.0 \%$, while the metabolizable energy amounted to $2903 \mathrm{kcal} / \mathrm{kg}$ of feed. The following traits were studied: average daily egg weight (g) and average weekly feed consumption according to Al Fayadh and Naji (1989). As for the feed conversion efficiency, it was calculated as stated by (Ibrahim, 2000), and the weekly egg production percentage was calculated on the basis of H.D. as mentioned by (Naji and Hanna, 1999). The weekly egg mass was calculated according to (AlQazzaz,2007), while the cumulative number of eggs was calculated according to (Naji,2007). The data were analyzed using a completely random design (CRD) to study the effect of the studied treatments on the various traits (SAS,2012), and the significant differences between the averages were compared using the Duncan (1955) polynomial test.

\section{RESULTS AND DISCUSSION}

Results in Table ( 1 ) indicate the effect of adding the aqueous and alcoholic extract for the Alkhalal date without pits and the dates pits on a Hen-Day egg production percentage for the 50 ages quail hens raised at high temperatures for 12 weeks. At all ages, the results indicated that all addition treatments significantly increased egg production, in favor of $\mathrm{T} 3$ and $\mathrm{T} 5$ compared with the control $(\mathrm{T}) 1$.
Results of the average weekly egg weight as affected by dietary treatments are shown in Table (2) .As listed in the hen-day egg production percentages, results of egg weight at most of the experimental periods indicate the superiority of dietary treatments compared with the control (T1). However, , both T3 and T5 recorded significantly better values compared to the others.

Results in Table ( 3 ) show the effect of adding the aqueous and alcoholic extract for the khalal date without pits and the dates pits on the egg mass traits of the 50 ages quail females bred at high temperatures for 12 weeks. The results obtained at 4, 6, 8, 10 and 12 weeks showed that all adding treatments were significantly excelled $(\mathrm{P} \leq 0.01)$ with $\mathrm{T} 3$ and $\mathrm{T} 5$ being better than the other treatments as well as the control one.

Results in Table (4) indicate the effect of the aqueous and alcoholic extract for the khalal date and date pits in the drinking water of the aged 50-day quail females raised at high temperatures for 12 weeks on the weekly feed consumption trait. There were no significant differences between the trial treatments at the second week, however, at the rest of the experimental period, feed consumption of added treatments differed significantly compared to the control(T1). The preference was in favor of $\mathrm{T} 3$ and $\mathrm{T} 5$, being higher than $\mathrm{T} 2$ and $\mathrm{T} 4$ and $\mathrm{T} 1$ as well.

Table 5 shows the results of the effect of adding the aqueous and alcoholic extract for the Alkhalal date and dates pits in drinking water on the trait of the feed conversion efficiency for the aged 50-day quail females raised at high temperatures for a period of 12 weeks .Parallel to data obtained for egg mass and feed consumption, results of feed conversion efficiency indicate the superiority of T3 and T5 which were significantly better than both $\mathrm{T} 2$ and T4 as well as the control (T1).

Table 6 shows the results of the effect of adding the aqueous and alcoholic extract for the khalal date Al-Zahdi without pits and dates pits in drinking water on the cumulative number of eggs for quail females aged 50 days bred at high temperatures for 12 weeks. The results 


\section{Mohammed Rasul Mahdi Jasim ${ }^{1}$ Dhia Khalil Ibrahim ${ }^{2}$}

showed that adding treatments were significantly superior $(\mathrm{P} \leq 0.01)$ compared with $\mathrm{T} 1$, and the preference was in favor of $\mathrm{T} 3$ and $\mathrm{T} 5$ by excelled $\mathrm{T} 2$ and $\mathrm{T} 4$.

The significant excelled in production traits when treating birds with the aqueous and alcoholic extract for the Al-Zahdi khalal date pits may be due to their content of steroid compounds with estrogenic activity (AlHaboubi, 1996), where it is possible that these compounds work to raise the concentration of estrogen in the blood, which leads to stimulation of gonadotrophin FSH and LH hormones, as these hormones increase the growth of ovarian follicles through their role in stimulating the formation of yolk in the liver, which increases the weight of the ovaries and increases its effectiveness for the production of mature eggs and the ovulation process (Sturkie, 2000).This leads to an increase in the weight and number of eggs produced. In addition, the increase in the estrogen hormone in the blood of the birds stimulates the tube glands in the bone area and thus leads to an increase in the secretion of albumin, which is one of the main components of the egg (Al Hasani ,2000), and so reflected on the increase in the weight and mass of the egg. Also, the significant excelled in some production traits when using all the extracts, especially the two treatments (T5) and (T3), is due to their content of active compounds classified as biologically active such as flavonoids, alkaloids, tannins, saponins and coumarins (Al-Qarawi et al.,2004 and Ben Sassi ,2018), which are classified as substances with pharmacological, therapeutic, antiinflammatory and antioxidant properties (AlFarsi et al., 2005; Habib et al., 2014).Or, the improvement in production traits may be due to the fact that the extracts contain vitamin E, where this vitamin sustains fatty substances and preserves them from oxidation as a result of birds' exposure to heat stress, where these substances contribute to the growth of ovarian follicles and with the presence of vitamin $\mathrm{E}$ as an antioxidant will work to maintain on the fats from oxidative stress so, become more suitable for digestion and absorption (Gel, 1999),Also, in conditions of heat stress, vitamin $\mathrm{E}$ protects unsaturated fatty acids from oxidation by free radicals, and thus this vitamin is classified as one of the best non-enzymatic antioxidants that have the ability to inhibit free radical production reactions, which usually form when the respiratory rate of birds increases during exposure to heat. Due to heat stress, this leads to the protection of fatty compounds that are involved in the production of egg components from oxidation (Englmaierova et al., 2011; AlDulaimi and Draid, 2018). In addition to the role of vitamin $\mathrm{E}$ in protecting hepatocytes from fat oxidation, this may lead to an increase in the weight of the ovarian follicles, and thus an increase in the weight of the yolk, which contributes to the increase in the weight and mass of eggs (Abdel-Maksoud, 2006), or the vitamin may work directly to maintain the normal functions of the processes and so the cells of the ovaries that regulate the secretion of its hormones (Bollengier-Lee et al., 1998). Giving the extracts containing this vitamin will contribute to increasing the amount of vitamin E consumed, and then the vitamin will contribute to preserving the fatty compounds that enter the formation of the yolk, which leads to an abundance of these substances and then the maturation of the ovarian follicles in a shorter time for the treatment of birds that have eaten extracts and this is what helps in increasing the percentage of egg production, weight and the number of cumulative eggs .The reason for the significantly excelled of the egg mass in the treatments that dealt with the extracts, especially T3 and T5, may be that the mass of eggs is affected by the weight of the eggs and the rate of production, so the two traits will directly affect the egg mass .The reason for the improvement in the feed conversion factor for birds in all addition factors is due to the fact that this trait is affected by the quality of the feed materials that make up the feed and the amount of feed consumed to produce a quantity of eggs, which was significantly higher due to the extracts content of some active compounds like pectin which improves the palatability of birds to the food, in addition to its role in slowing down the passage of the nutrient into the gastrointestinal 
tract, which contributes to the efficiency of utilizing the feed and increasing the absorption process Al- Manhal (2004). The reason for the improvement of the feed conversion efficiency is also due to the significant increase in the cumulative number of eggs and the rate of egg mass when using the extracts, especially for T5 and T3, which are affected by the weight of eggs and the rate of egg production. This means that this trait gave the best economic index of the relationship between the amount of feed consumed and the amount of eggs produced in the addition treatments compared with $\mathrm{T} 1$.

\section{CONCLUSION}

The addition of aqueous and alcoholic extracts for the Al-khalal date and date pits at a rate of $300 \mathrm{mg} /$ liter of drinking water contributed significantly excelled and increase in the productive traits represented by the weekly feed consumption, the average weekly egg weight, the mass and the weekly cumulative number of eggs, as well as a significant improvement in feed conversion efficiency at all the experiment weeks. The preference was in favor of the two treatments T3 and T5 for the Japanese quail hens raised at high temperatures for 12 weeks which consumed drinking water containing 300 $\mathrm{mg}$ of the alcoholic extract of the fruit and the pits of Khalal Zahdi date, respectively.

Table (1): The effect of adding the aqueous and alcoholic extract for the Al-Zahdi khalal date without pits and Al-Zahdi khalal dates pits on the egg production percentage (H.D\%) of quail hens aged 50 days reared at high temperature for 12 weeks (mean \pm standard error).

\begin{tabular}{|c|c|c|c|c|c|c|}
\hline \multirow[t]{2}{*}{ Weeks } & \multicolumn{5}{|c|}{ Treatments } & \multirow{2}{*}{$\begin{array}{c}\text { Significant } \\
\text { level }\end{array}$} \\
\hline & T1 & $\mathbf{T 2}$ & T3 & T4 & T5 & \\
\hline 2 & $\vee 9.0 \pm \cdot .90^{b}$ & $84.11 \pm 0.84^{\mathrm{a}}$ & $87.30 \pm 1.38^{\mathrm{a}}$ & $84.44 \pm 1.77^{\mathrm{a}}$ & $87.62 \pm 0.95^{\mathrm{a}}$ & $* *$ \\
\hline 4 & $70.75 \pm 0.84^{\mathrm{c}}$ & $78.41 \pm 0.84^{\mathrm{b}}$ & $85.71 \pm 1.10^{\mathrm{a}}$ & $78.73 \pm 0.84^{b}$ & $85.71 \pm 0.01^{\mathrm{a}}$ & ** \\
\hline 6 & $70.33 \pm 1.02^{c}$ & $80.95 \pm 0.55^{b}$ & $84.98 \pm 1.83^{\mathrm{a}}$ & $79.68 \pm 0.84^{b}$ & $84.44 \pm 0.63^{\mathrm{a}}$ & $* *$ \\
\hline 8 & $79.04 \pm 2.63^{b}$ & $83.78 \pm 1.45^{\mathrm{ab}}$ & $86.73 \pm 1.02^{\mathrm{a}}$ & $82.86 \pm 1.45^{\mathrm{ab}}$ & $85.39 \pm 0.32^{\mathrm{a}}$ & $*$ \\
\hline 10 & $56.41 \pm 0.73^{\mathrm{c}}$ & $63.26 \pm 1.06^{b}$ & $73.04 \pm 1.14^{\mathrm{a}}$ & $63.49 \pm 1.38^{\mathrm{b}}$ & $73.40 \pm 1.16^{\mathrm{a}}$ & $* *$ \\
\hline 12 & $55.05 \pm 0.68^{c}$ & $58.15 \pm 0.02^{b}$ & $65.21 \pm 1.01^{\mathrm{a}}$ & $58.73 \pm 0.84^{b}$ & $65.40 \pm 0.84^{\mathrm{a}}$ & ** \\
\hline
\end{tabular}

The different letters within the same row indicate the presence of significant differences between the treatments, ** means the presence of significant differences at the level $(\mathrm{p}<0.01)$. (T1) control treatment without addition, (T2and T3) adding $300 \mathrm{mg} \backslash \mathrm{L}$ of the aqueous and alcoholic extract of Al-Zahdi Khalal, (T4and'T5) adding $300 \mathrm{mg} \backslash \mathrm{L}$ of the aqueous and alcoholic extract of AL-Zahdi khalal date pits, respectively. 
Mohammed Rasul Mahdi Jasim ${ }^{1}$ Dhia Khalil Ibrahim²

Table (2): The effect of adding the aqueous and alcoholic extract for the Al-Zahdi khalal date and Al-Zahdi khalal date pits on the average weekly egg weight $(\mathrm{g})$ of the aged 50-day quail hens reared at high temperature for 12 weeks (mean \pm standard error).

\begin{tabular}{|c|c|c|c|c|c|c|}
\hline \multirow{2}{*}{ Weeks } & \multicolumn{5}{|c|}{ Treatments } & Significant \\
& level \\
\hline 2 & T1 & T2 & T3 & T4 & T5 & $*$ \\
4 & $11.86 \pm 0.08^{\mathrm{b}}$ & $12.17 \pm 0.03^{\mathrm{a}}$ & $12.27 \pm 0.08^{\mathrm{a}}$ & $12.29 \pm 0.10^{\mathrm{a}}$ & $12.38 \pm 0.12^{\mathrm{a}}$ & $* *$ \\
6 & $11.57 \pm 0.12^{\mathrm{c}}$ & $11.93 \pm 0.07^{\mathrm{b}}$ & $12.32 \pm 0.02^{\mathrm{a}}$ & $12.01 \pm 0.09^{\mathrm{b}}$ & $12.54 \pm 0.05^{\mathrm{a}}$ & $* *$ \\
8 & $11.84 \pm 0.08^{\mathrm{c}}$ & $12.07 \pm 0.15^{\mathrm{bc}}$ & $12.75 \pm 0.01^{\mathrm{a}}$ & $12.30 \pm 0.10^{\mathrm{b}}$ & $12.83 \pm 0.03^{\mathrm{a}}$ & $* *$ \\
10 & $11.47 \pm 0.12^{\mathrm{c}}$ & $11.91 \pm 0.04^{\mathrm{b}}$ & $12.45 \pm 0.06^{\mathrm{a}}$ & $11.96 \pm 0.08^{\mathrm{b}}$ & $12.55 \pm 0.08^{\mathrm{a}}$ & $* *$ \\
12 & $11.36 \pm 0.03^{\mathrm{c}}$ & $11.64 \pm 0.07^{\mathrm{d}}$ & $12.35 \pm 0.07^{\mathrm{b}}$ & $11.90 \pm 0.04^{\mathrm{c}}$ & $12.59 \pm 0.06^{\mathrm{a}}$ & $* *$ \\
\hline
\end{tabular}

The different letters within the same row indicate the presence of significant differences between the treatments, ** means the presence of significant differences at the level ( $p<0.01)$. (T1) control treatment without addition, (T2and T3) adding $300 \mathrm{mg} \backslash \mathrm{L}$ of the aqueous and alcoholic extract of Al-Zahdi Khalal, (T4and'T5) adding $300 \mathrm{mg} \backslash \mathrm{L}$ of the aqueous and alcoholic extract of AL-Zahdi khalal date pits, respectively.

Table (3): Effect of addition of aqueous and alcoholic extract for the Al-Zahdi khalal date without pits and Al-Zahdi khalal dates pits on egg mass (g/week) for aged 50 days quail hens reared at high temperature for 12 weeks (mean \pm standard error).

\begin{tabular}{|c|c|c|c|c|c|c|}
\hline \multirow{2}{*}{ Weeks } & \multicolumn{5}{|c|}{ Treatments } & Significant \\
& level \\
\hline & T1 & T2 & T3 & T4 & T5 & $* *$ \\
4 & $65.62 \pm 1.14^{\mathrm{c}}$ & $71.63 \pm 0.56^{\mathrm{b}}$ & $74.98 \pm 1.18^{\mathrm{ab}}$ & $72.65 \pm 1.72^{\mathrm{ab}}$ & $75.94 \pm 0.82^{\mathrm{a}}$ & $* *$ \\
6 & $56.85 \pm 1.10^{\mathrm{c}}$ & $65.49 \pm 0.89^{\mathrm{b}}$ & $73.94 \pm 1.09^{\mathrm{a}}$ & $66.21 \pm 1.11^{\mathrm{b}}$ & $75.24 \pm 0.28^{\mathrm{a}}$ & $* * 1.58^{\mathrm{c}}$ \\
8 & $58.27 \pm 0.96^{\mathrm{c}}$ & $68.41 \pm 0.79^{\mathrm{b}}$ & $75.82 \pm 1.58^{\mathrm{a}}$ & $68.61 \pm 1.17^{\mathrm{b}}$ & $75.84 \pm 0.70^{\mathrm{a}}$ & $* *$ \\
10 & $64.45 \pm 2.42^{\mathrm{c}}$ & $69.88 \pm 1.44^{\mathrm{b}}$ & $75.60 \pm 0.51^{\mathrm{a}}$ & $69.37 \pm 0.84^{\mathrm{b}}$ & $75.04 \pm 0.38^{\mathrm{a}}$ & $* *$ \\
12 & $45.31 \pm 0.60^{\mathrm{c}}$ & $51.54 \pm 0.66^{\mathrm{b}}$ & $63.12 \pm 0.95^{\mathrm{a}}$ & $52.90 \pm 1.05^{\mathrm{b}}$ & $64.67 \pm 0.87^{\mathrm{a}}$ & $* *$ \\
\hline
\end{tabular}

The different letters within the same row indicate the presence of significant differences between the treatments, ** means the presence of significant differences at the level $(\mathrm{p}<0.01)$. (T1) control treatment without addition, (T2and T3) adding $300 \mathrm{mg} \backslash \mathrm{L}$ of the aqueous and alcoholic extract of Al-Zahdi Khalal, (T4and'T5) adding $300 \mathrm{mg} \backslash \mathrm{L}$ of the aqueous and alcoholic extract of AL-Zahdi khalal date pits, respectively. 3

Table (4): The effect of adding the aqueous and alcoholic extract for the Al-Zahdi khalal date and Al-Zahdi khalal dates pits on the average weekly feed consumption (g) for quail hens aged 50 days reared at high temperature for 12 weeks (mean \pm standard error).

\begin{tabular}{|c|c|c|c|c|c|c|}
\hline \multirow[t]{2}{*}{ Weeks } & \multicolumn{5}{|c|}{ Treatments } & \multirow{2}{*}{$\begin{array}{c}\text { Significant } \\
\text { level }\end{array}$} \\
\hline & T1 & T2 & T3 & T4 & T5 & \\
\hline 2 & $251.07 \pm 15.35$ & $266.67 \pm 1.39$ & $269.05 \pm 0.25$ & $268.22 \pm 1.30$ & $270.58 \pm 0.70$ & NS \\
\hline 4 & $263.82 \pm 0.84^{\mathrm{C}}$ & $268.00 \pm 0.39^{b}$ & $270.00 \pm 0.39^{a}$ & $268.45 \pm 0.22^{b}$ & $270.45 \pm 0.22^{\mathrm{a}}$ & 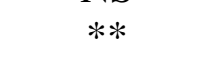 \\
\hline 6 & $265.38 \pm 0.61^{\mathrm{b}}$ & $268.87 \pm 0.14^{\mathrm{a}}$ & $269.67 \pm 0.21^{\mathrm{a}}$ & $268.98 \pm 0.28^{\mathrm{a}}$ & $269.80 \pm 0.10^{\mathrm{a}}$ & ** \\
\hline 8 & $263.44 \pm 0.76^{b}$ & $267.38 \pm 1.19^{b}$ & $268.59 \pm 1.44^{\mathrm{a}}$ & $268.62 \pm 0.32^{\mathrm{a}}$ & $269.84 \pm 0.09^{\mathrm{a}}$ & $* *$ \\
\hline 10 & $197.52 \pm 6.25^{c}$ & $239.59 \pm 1.94^{b}$ & $266.37 \pm 3.29^{\mathrm{a}}$ & $250.04 \pm 5.03^{b}$ & $269.08 \pm 2.04^{\mathrm{a}}$ & $* *$ \\
\hline 12 & $200.79 \pm 2.09^{c}$ & $227.77 \pm 3.48^{b}$ & $247.88 \pm 1.16^{\mathrm{a}}$ & $229.62 \pm 2.94^{\mathrm{b}}$ & $255.42 \pm 0.52^{\mathrm{a}}$ & $* *$ \\
\hline
\end{tabular}

The different letters within the same row indicate the presence of significant differences between the treatments, ** means the presence of significant differences at the level $(p<0.01)$. (T1) control treatment without addition, (T2and T3) adding $300 \mathrm{mg} \backslash \mathrm{L}$ of the aqueous and alcoholic extract of Al-Zahdi Khalal, (T4and'T5) adding $300 \mathrm{mg} \backslash \mathrm{L}$ of the aqueous and alcoholic extract of AL-Zahdi khalal date pits, respectively. 
aqueous extract, alcoholic extract, Al-Zahdi Khalal dates, Al-Zahdi dates pits, quail.

Table (5): The effect of adding the aqueous and alcoholic extract for the Al-Zahdi khalal date without pits and Al-Zahdi khalal dates pits on the feed conversion factor (g feed/g eggs) for aged 50-day quail hens reared at High temperature for 12 weeks (mean \pm standard error).

\begin{tabular}{|c|c|c|c|c|c|c|}
\hline \multirow[t]{2}{*}{ Weeks } & \multicolumn{5}{|c|}{ Treatments } & \multirow{2}{*}{$\begin{array}{c}\text { Significant } \\
\text { level }\end{array}$} \\
\hline & T1 & T2 & T3 & T4 & T5 & \\
\hline 2 & $3.82 \pm 0.19$ & $3.72 \pm 0.03$ & $3.59 \pm 0.05$ & $3.70 \pm 0.08$ & $3.57 \pm 0.03$ & NS \\
\hline 4 & $4.63 \pm 0.08^{\mathrm{a}}$ & $4.09 \pm 0.06^{\mathrm{b}}$ & $3.65 \pm 0.06^{\mathrm{c}}$ & $4.06 \pm 0.07^{b}$ & $3.59 \pm 0.02^{c}$ & $* *$ \\
\hline 6 & $4.56 \pm 0.08^{\mathrm{a}}$ & $3.93 \pm 0.05^{\mathrm{b}}$ & $3.56 \pm 0.07^{\mathrm{c}}$ & $3.92 \pm 0.06^{\mathrm{b}}$ & $3.56 \pm 0.03^{c}$ & $* *$ \\
\hline 8 & $4.10 \pm 0.15^{\mathrm{a}}$ & $3.83 \pm 0.09^{\mathrm{ab}}$ & $3.60 \pm 0.04^{\mathrm{bc}}$ & $3.87 \pm 0.05^{\mathrm{a}}$ & $3.55 \pm 0.02^{\mathrm{c}}$ & $* *$ \\
\hline 10 & $4.36 \pm 0.11^{\mathrm{b}}$ & $4.65 \pm 0.02^{\mathrm{a}}$ & $4.22 \pm 0.04^{\mathrm{bc}}$ & $4.73 \pm 0.02^{\mathrm{a}}$ & $4.16 \pm 0.03^{c}$ & $* *$ \\
\hline 12 & $4.59 \pm 0.09^{\mathrm{ab}}$ & $4.79 \pm 0.08^{\mathrm{a}}$ & $4.41 \pm 0.07^{\mathrm{b}}$ & $4.73 \pm 0.05^{\mathrm{a}}$ & $4.48 \pm 0.06^{\mathrm{b}}$ & $* *$ \\
\hline
\end{tabular}

The different letters within the same row indicate the presence of significant differences between the treatments, ** means the presence of significant differences at the level ( $p<0.01)$. (T1) control treatment without addition, (T2and T3) adding $300 \mathrm{mg} \backslash \mathrm{L}$ of the aqueous and alcoholic extract of Al-Zahdi Khalal, (T4and'T5) adding $300 \mathrm{mg} \backslash \mathrm{L}$ of the aqueous and alcoholic extract of AL-Zahdi khalal date pits, respectively.

Table (6): The effect of adding the aqueous and alcoholic extract for the Al-Zahdi khalal date without pits and Al-Zahdi khalal dates pits on the cumulative number of eggs (egg/quail hen) of aged 50-day quail females reared at High temperature for 12 weeks (mean \pm standard error).

\begin{tabular}{|c|c|c|c|c|c|c|}
\hline \multirow{2}{*}{ Weeks } & \multicolumn{5}{|c|}{ Treatments } & Significant \\
& level \\
\cline { 2 - 7 } & T1 & T2 & T3 & T4 & T5 & $* *$ \\
4 & $5.54 \pm 0.07^{\mathrm{b}}$ & $5.91 \pm 0.06^{\mathrm{a}}$ & $6.11 \pm 0.10^{\mathrm{a}}$ & $5.91 \pm 0.12^{\mathrm{a}}$ & $6.14 \pm 0.07^{\mathrm{a}}$ & $* *$ \\
6 & $4.91 \pm 0.06^{\mathrm{c}}$ & $5.49 \pm 0.06^{\mathrm{b}}$ & $6.00 \pm 0.08^{\mathrm{a}}$ & $5.51 \pm 0.06^{\mathrm{b}}$ & $6.00 \pm 0.00^{\mathrm{a}}$ & $* *$ \\
8 & $4.93 \pm 0.07^{\mathrm{c}}$ & $5.76 \pm 0.12^{\mathrm{ab}}$ & $5.96 \pm 0.12^{\mathrm{a}}$ & $5.58 \pm 0.06^{\mathrm{b}}$ & $5.91 \pm 0.04^{\mathrm{a}}$ & $* *$ \\
10 & $5.53 \pm 0.19^{\mathrm{b}}$ & $5.86 \pm 0.10^{\mathrm{ab}}$ & $6.07 \pm 0.07^{\mathrm{a}}$ & $5.80 \pm 0.10^{\mathrm{ab}}$ & $5.98 \pm 0.02^{\mathrm{a}}$ & $* *$ \\
12 & $3.95 \pm 0.05^{\mathrm{c}}$ & $4.43 \pm 0.07^{\mathrm{b}}$ & $5.11 \pm 0.08^{\mathrm{a}}$ & $4.45 \pm 0.10^{\mathrm{b}}$ & $5.14 \pm 0.08^{\mathrm{a}}$ & $* *$ \\
\hline
\end{tabular}

The different letters within the same row indicate the presence of significant differences between the treatments, ** means the presence of significant differences at the level $(p<0.01)$. (T1) control treatment without addition, (T2and T3) adding $300 \mathrm{mg} \backslash \mathrm{L}$ of the aqueous and alcoholic extract of Al-Zahdi Khalal, (T4and'T5) adding $300 \mathrm{mg} \backslash \mathrm{L}$ of the aqueous and alcoholic extract of AL-Zahdi khalal date pits, respectively.

\section{REFERENCES}

Abdel-Maksoud,A.A.A.2006..Effect

of

vitamin $\mathrm{E}$ supplementation on performanc of laying hens during summer months under thedessertconditions,Egypt.Poult.Sci.29(111 ):873-889.

Al Manhal, A.J.A. 2004. Preparing Alkhalal date powder from some varieties of local dates, studying its specific characteristics and using it in making bread and biscuits. Master thesis. College of Agriculture University of Basra.

Al-Dulaimi,S. T.Y and T. Draid. 2018. The protective effect of adding methionine or vitamin $\mathrm{E}$ or mixing them in some of the physiological and chemical traits of broilers due to exposure to heat stress. Basra Journal of Veterinary Sciences. Volume 17; Issue 3.

AlFarsi,M.,C.Alasalvar,A.Morris,V.Baronan dF.Shahidi.2005.Compositional and sensory characteristics of three native sun dried date (Phoenix dactyllifera $\mathrm{L}$.) varieties grown in Oman. J. Agric. Food. Chem. 53, 7586-7591.

Al-Fayadh, H. and S.A.Naji. 1989. Poultry Products Technology. First edition. Ministry of Higher Education and Scientific Rsearch. (in Arabic)

Al-Haboubi,B. T. 1996. Extraction of estrogenic steroid compounds from date 
seeds and testing of their biological efficiency. Master Thesis. College of Agriculture - University of Baghdad.

Al Hasani,D.H. 2000. Physiology of poultry, Directorate of Dar Al Kutub for Printing and Publishing, Baghdad, Ministry of Higher Education and Scientific Research, College of Agriculture, University of Baghdad. (in Arabic)

Al-Juraisy,Y. H. 2016. Modulatory Effects of Date Palm (Phoenix dactylifera L.) pits extract against ethinylestradiol induced genotoxic damage in cultured human lymphocytes . Iraqi Journal of Science. Vol. 57, No.1C, pp: 576-582.

Al-Khailani, F.M. 2009. The effect of adding different levels of anise seeds and Hibiscus flowers to the diet on the performance efficiency of laying hens, quail birds and broiler chickens, PhD thesis - College of Agriculture - University of Baghdad.

Al-Laith,A.A. 2007.Antioxidant activity of Bahraini date palm 9(phonix dactylifera L.) fruit of various cultivars .Int j.food sci.technol,43;1033-1040.

Al-Qazzaz,M.F. A.R. 2007. A comparison of the effect of using two types of probiotic and the mixture between them on the productive performance of laying hens and roosting semen characteristics. Master Thesis. College of Agriculture - University of Baghdad.

AlQarawi,A.,H.M.Mousa,B.E.H.Ali,H.Abdel -Rahman andS.A.EIMougy.2004.Protective effect of extracts from dates (Phoenix dactylifera L.) on carbon tetrachloride induced hepatotoxicity in rats. Inter. J. Appl. Res. Med. 2, 176-180.

Al-Rahawi,G. A. 2010. The effect of vitamins $\mathrm{E}$ and $\mathrm{C}$ and their mixture on some physiological and productive traits of quail coturinx Coturinx, Master Thesis, College of Agriculture and Forestry - University of Mosul.

Al-Sawaf, D.I.M.2011. Qualitative and quantitative analysis of amino acids of protein isolated from date seeds (Phoenix dactyl lifera L.) and estimation of its molecular weight by gel filtration technique (first part). Al-Rafidain Science Journal. Vol 22. Issue 2. Pp. 128-111.

Al-Turk,N.F.2008. Dates, food and medicine, Food Technology Research Institute, Shams Foundation for Publishing and Media. Cairo. Pp. 1-160.

Awadalla,I.M.,Y.A.Maarck.,M.I.Mohamed and M.S.Farghaly.2002. Response to partial replacement of yellow corn in rahmani lambs rations with ground date seeds on growth rate, digestion coefficients, rumen fermentation and carcass traits. Egyptian J.Nut. Foods. 5(2), 139-154.

Ben Sassi,S. 2018. Evaluation of the antioxidant and antibacterial activity of the phenolic compounds of some varieties of dates from the Rig Valley region by different methods. $\mathrm{PhD}$ thesis. Faculty of Mathematics and Material Sciences - Qasidi Merbah and Ouargla University.

BollengierLee,S.,M.A.Mitchell.D.B.Utomoan d P.E.Williams.1998. Influence of high dietary vitamin $\mathrm{E}$ supplementation on egg production and plasma characteristic in hens subjected to heat stress. Brit . Poult .sci ., 39:106-112.

Duncan, D.B. 1955. Multiple rang and multiple F-test. Biometrics. 11: 4-42.

El-Lethey ,A.H ., V, Jungi .T. B, Wechsler. 2000 . Stress and feather pecking in laying hens relation to housing condtion . Br . Poult . Sci . , 41, $22-28$.

Englmaierova,M.,I.Bubancova,T.VitandM.S krivan.2011.The effect of lycopene and vitamin $\mathrm{E}$ on growth performance, quality And oxidative stability of chicken leg meat. Czech J. Anim. Sci., 56 (12): 536-543.

Gel,T. E.H.1999. The effect of adding different levels of vitamin $\mathrm{E}$ on preserving fertility and hatching characteristics of advanced white lichen chickens. Master's thesis, College of Agriculture, University of Baghdad.

Ghnimi,S.,U.Syed,K.Azharul and K.Afaf.2017.Date fruit (Phoenix dactylifera L.): An underutilized food seeking industrial valorization. NFS Journal 6: 1-10.

Habib,H.M.,C.Platat,E.Meudec,V.Cheynier and W.H.Ibrahim.2014. Polyphenolic 
aqueous extract, alcoholic extract, Al-Zahdi Khalal dates, Al-Zahdi dates pits, quail.

compounds in date fruit seed(Phoenix dactylifera): characterisation and quanti fi cation byusing UPLC-DAD-ESI-MS. J. Sci. Food Agri. 94 (6), 1084.

Harborne, J.B.,T.J. Mabray and H. Mabray.1975.Physiology and function of Flavonoids .pp:970.The Flavaonoids Academicpress. Now York.

Ibrahim, D. K and D. H. Al-Hasani, 2002. The effect of adding ammonium chloride and potassium salt in drinking water during different periods of the day and fasting on the performance of broilers exposed to high environmental temperature. The Second Conference on Agricultural Research. Animal Production - Food Science. Economic and Social Sciences - Pests and Diseases. Faculty of Agriculture - Cairo University. Special Edition, pages 582--588.

Ibrahim, I. K.,2000. Feeding poultry. The second edition of the Ministry of Higher
Education and Scientific ,Research. Mosul University Press.

Naji, S.A. 2007. Manual of commercial production of laying hens. First edition. Al Akhawain Modern Press.

Naji, S. A.and Hanna A. K.,1999. Handbook of Laying Hens Breeding, Heba Press. Arab Union for Food Industries.

\section{National Research}

(NRC).1994.Nutrient requirements of domestic animals.Nutrint reqirements of poultry, 9 thedn. Washington DC, National Academy Press.

SAS, 2012.Statistical analysis system, User's guide. Statistical. version 9.1th ed. SAS. Inst. Inc. Cary. N.C. USA.

Siegel , H.S. 1995 . Stress strain andresistance . Br . Poult . Sci ., $36: 3-22$.

Sturkie,P.D.2000. Avian Physiology. 5th ed. New york, Heidelberg, Berlin,Spriner Verlag.

\section{الملخص العربى

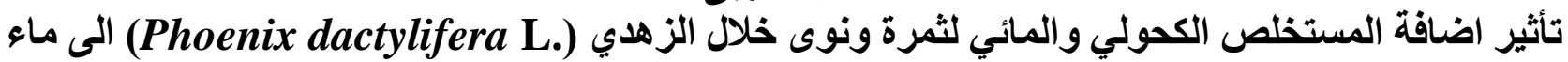

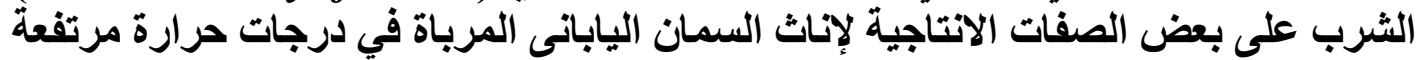

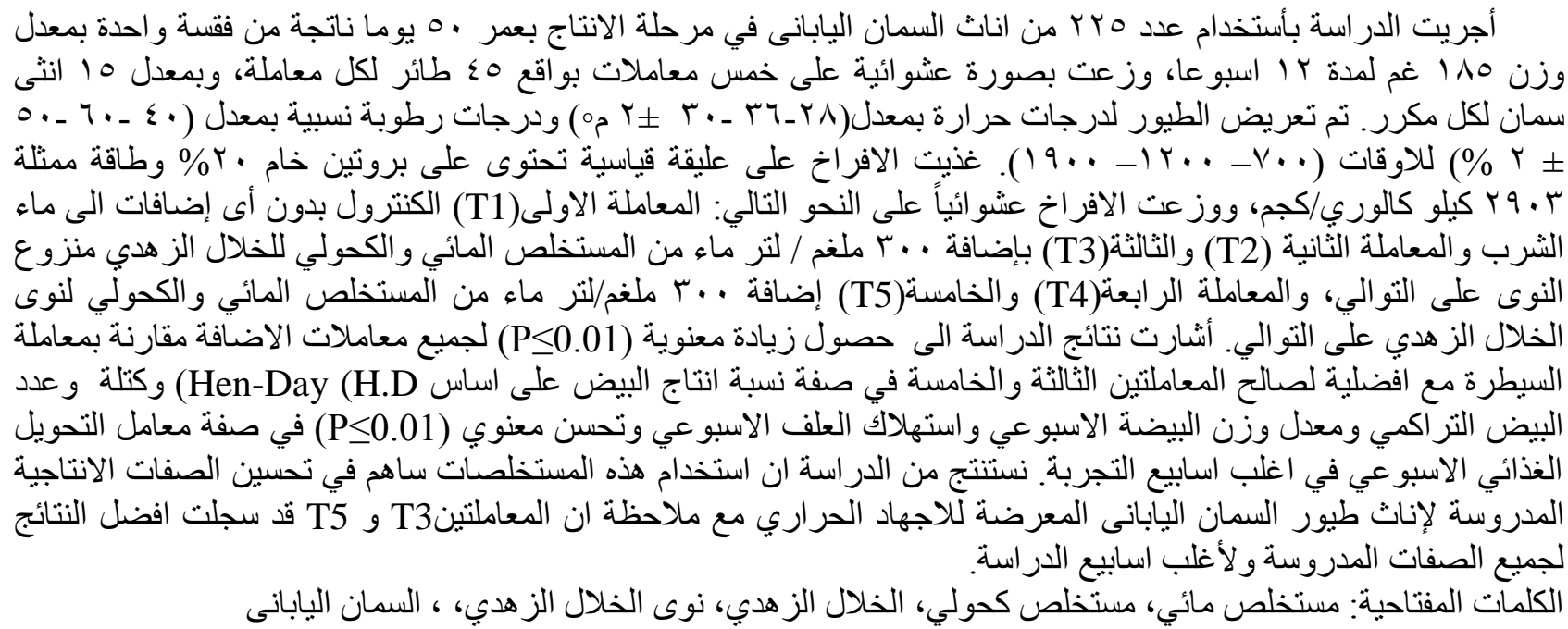

